\title{
REPORT \\ OF AIDP UKRAINIAN NATIONAL GROUP 2020
}

We are glad to inform AIDP Board of Directors about progress of AIDP Ukrainian National Group 2020 on the next directions.

1. AIDP Ukrainian National Group is united 15 members: Prof. Vasyl Tatsiy, Prof. Yuri Baulin (President), Prof. Vyacheslav Borisov (Vice-President), Prof. Nataliya Gutorova (Vice-President), Prof. Mykhaylo Shepitko (Secretary), Prof. Liudmyla Demydova, Prof. Serhiy Denysov, Prof. Paul Fries, Assoc. Prof. Olena Kharytonova, Assoc. Prof. Kostiantyn Zadoia, Prof. Roman Veresha, Assoc. Prof. Oleksander Radutniy, Assoc. Prof. Nadia Shulzhenko, Assoc. Prof. Oksana Senatorova, Prof. Mykola Karchevskyi.

2. AIDP Ukrainian National Group was co-organizer of Discussion Panel «Rome Statute of International Criminal Court: Problems of Implementation to National Legislation of Ukraine» (Kharkiv, Ukraine, 25 September 2020). As a result of this Scientific Events Organizers prepared: 1) Resolution of the Discussion Panel; 2) gave start to procedure of implementation Rome Statute of International Criminal Court to Ukrainian Criminal Law; 3) Collection of Scientific Reports. More information about event: https://nlu.edu.ua/новини/ ратифікація-римського-статуту-стала/.

3. AIDP Ukrainian National Group was a mover of Reformation of Criminal Law in Ukraine. Yuri Baulin (President of AIDP Ukrainian National Group) is head of Committee of Reformation of Criminal Law in Ukraine supported by Volodymyr Zelensky (President of Ukraine). During dozen meetings of the Committee it was prepared Project of New Criminal Code of Ukraine. More information about Project: https://newcriminalcode.org.ua/criminal-code.

4. Discussions of New Criminal Code of Ukraine were made during next Scientific events, where members of AIDP Ukrainian National Group took part: 1) Internet conference «Legal Basis of Epidemic Security: Challenges and Perspectives» (Poltava, Ukraine, 29 April 2020); 2) Lviv Forum of Criminal 
Justice (Lviv, Ukraine, 17-19 September 2020); 3) Webinar «Project of General Part pf New Criminal Code of Ukraine in the Contest of Modern Theory of Criminal Law and International Standards of Criminal Legislation» (Kharkiv, Ukraine, 18 October 2020); 4) International Scientific Conference «Reformation of Criminal Legislation of Ukraine: Nowadays and Future» (Kharkiv, Ukraine, 22-23 October 2020); 5) Autumn School of Criminal Law «Laboratory of Criminal Law-Making» (Novomoskovsk, Ukraine, 11-13 November 2020); 6) Webinar «Modern Theory and Principles of Criminal Law and Ways of its Reflection in Special Part of Criminal Code of Ukraine Project» (Kharkiv, Ukraine, 18 November 2020).

5. Members of AIDP Ukrainian National Group is planned to take part in th next scientific events 2020: 1) Webinar «Evaluation of the Project of Criminal Code of Ukraine on the Correspondence with Criminal Law Principles and International Standards» (Kharkiv, Ukraine, 3 December 2020); 2) Medico-legal Forum (Poltava, Ukraine, 11-12 December 2020).

6. AIDP Ukrainian National Group supported publication of Wiadomosci Liekarskie 12/2019 with scientific articles devoted to legal problems of fighting against COVID-19 consequences. More information about it: https://wiadlek.pl.

7. Members of AIDP Ukrainian National Group is published dozen publications, included: 1) Conceptual Basis of New Edition of Criminal Code of Ukraine. Collection of Scientific Reports, 17-19 October 2019. Kharkiv: «Pravo» Publishing House, 2020. 500 p.; 2) Tatsiy V. Selected Works: Monographs, Comments, Textbooks, Articles. Ed. by Yu. Bytiak, Yu. Baulin, L. Demidova. Kharkiv: «Pravo» Publishing House, 2019; 3) Criminal Law of Ukraine: textbook. Ed. by V. Tastiy, V. Borisov, etc. in 2 vol. Kharkiv: «Pravo» Publishing House, 2020. Vol. 1. «General Part». 584 p. Vol 2. «Special Part». 768 p.; 4) Bulletin of Ukrainian Association of Criminal Law. Vol. 1(13). 2020. URL: http://vakp.nlu.edu.ua/issue/view/12594 5) Current problems of the penal law and criminology. Aktuelle Probleme des Strafrechts und der Kriminologi. Edited by 
E. W. Pływaczewski, E. M. Guzik-Makaruk. Warszawa: Wydawnictwo C. H. Beck, 2019. 874 p. P. 44-625; 6) Vyunyk M., Karchevskyi M., Arlanova O. Criminal Law Regulation: Realities and Perspectives (analytic materials). Kharkiv: «Pravo» Publishing House, 2020. 212 p. 7) Shepitko M. Criminal Politics in the Sphere of Justice Bodies Activities' Support. Kharkiv: Apostille Publishing House, 2021. 180 p.; etc.

8. Secretary of AIDP Ukrainian National Group Mykhaylo Shepitko took part in the Board of Directors meeting with verbal and online report of Ukrainian National Group activities 2020 (Paris, France, 25 September 2020).

9. AIDP Ukrainian National Group have started own new scientific circle and appointed rappourteurs to the XXI AIDP Congress «Artificial Intelligence and Criminal Justice» by the next sections:

1) Traditional Criminal Law Categories and AI: Crisis or Palingenesis? (Assoc. Prof. Oleksander Radutniy, radut12@gmail.com, Prof. Mykola Karchevskyi);

2) Offences in the Criminal Code (Assoc. Prof. Oleksander Radutniy, radut12@gmail.com, Prof. Mykola Karchevskyi);

3) AI and Administration of Justice: Predictive Policing and Predictive Justice (Prof. Valery Shepitko, Prof. Mykhaylo Shepitko, shepitko.michael@gmail.com);

4) International Perspectives on AI: Challenges for Judicial Cooperation and International Humanitarian/Criminal Law (Prof. Mykhaylo Shepitko, shepitko.michael@gmail.com, Assoc. Prof. Oksana Senatorova)».

\author{
Mykhaylo Shepitko, \\ Secretary \\ of AIDP Ukrainian National Group
}

